\title{
In vivo evaluation of pharmacological properties of Argentine stingless bee geopropolis
}

\author{
Ivana Y. Brodkiewicz ${ }^{1,2}$, Marcos A. Reynoso ${ }^{1}$ and Nancy R. Vera ${ }^{1 *}$ (D)
}

\begin{abstract}
Background: Propolis is a natural product that has been widely utilized as medicine and dietary supplement because of its broad biological activities. However, although meliponide hive products have many advantages, meliponiculture has not yet become popular in Argentina, and few scientific studies on its chemical composition and/or its bioactive properties were reported, so the use of stingless bee propolis Argentine in popular medicine continues to be based on empirical knowledge.

Our work aims to evaluate in vivo anti-inflammatory, antitussive and expectorant activities, and acute toxicity of the Argentine geopropolis ethanol extracts of two stingless bee's species, Scaptotrigona jujuyensis Schrottky and Tetragonisca fiebrigi Schwarz. Wistar male rats were used for all in vivo studies. Anti-inflammatory activities were evaluated through carrageenan-induced edema and cotton pellet-induced granuloma formation. Antitussive activity was assessed against ammonia-induced cough. Expectorant activity was measured by volume of phenol red in the rats' tracheas. The extract doses tested were 125, 250, 500, and $1000 \mathrm{mg} / \mathrm{kg}$ (p.o.). The safety was evaluated with test of acute toxicity (48 h).

Results: The results showed that S. jujuyensis and T. fiebrigi propolis $(1000 \mathrm{mg} / \mathrm{kg})$ significantly reduced the carrageenaninduced edema and cotton pellet-induced granuloma formation $3 \mathrm{~h}$ post-dosing. In the ammonia liquor-induced cough, both propolis significantly enhanced the latent period and reduced cough frequency as compared with those of the negative control. However, they did not increase the expulsion of red phenol in the treated rats.
\end{abstract}

Conclusions: This study shows that ethanol extracts of S. jujuyensis and T. fiebrigi propolis have anti-inflammatory and antitussive effects. These findings would justify the use of geopropolis in medicine as a potential phytotherapeutic product.

Keywords: Antitussive activity, Expectorant activity, Anti-inflammatory activity, Acute toxicity, Scaptotrigona jujuyensis, Tetragonisca fiebrigi

\section{Background}

A third of the food we eat is available thanks to pollination, and about half of the animals that pollinate plants are bees [1]. The Meliponini tribe belongs to the group of corbiculated bees of the Apinae subfamily and groups all those bees known as "stingless bees" found in the tropical

\footnotetext{
* Correspondence: veranr@gmail.com; nrvera@fbqf.unt.edu.ar

'Facultad de Bioquímica, Química y Farmacia, Cátedra de Farmacoquímica, Inst. de Estudios Farmacológicos, Universidad Nacional de Tucumán, Ayacucho 471, 4000 Tucumán, Argentina

Full list of author information is available at the end of the article
}

and subtropical areas of the world. Together with honey bees (Apis mellifera), they are the only ones that have highly social behavior (eusociality: in Greek "eu": "good" + "social" is the highest level of social organization that occurs in certain animals). Before the arrival of the settlers who introduced the common bee (Apis mellifera), the stingless bees were the only ones that stored honey in the hives, and many indigenous cultures of South and Central America employed their honey, propolis, wax, and pollen [2]. Stingless bees in Argentina are distributed in three

\section{Springer Open}

(ㅇ The Author(s). 2020 Open Access This article is licensed under a Creative Commons Attribution 4.0 International License, which permits use, sharing, adaptation, distribution and reproduction in any medium or format, as long as you give appropriate credit to the original author(s) and the source, provide a link to the Creative Commons licence, and indicate if changes were made. The images or other third party material in this article are included in the article's Creative Commons licence, unless indicated otherwise in a credit line to the material. If material is not included in the article's Creative Commons licence and your intended use is not permitted by statutory regulation or exceeds the permitted use, you will need to obtain permission directly from the copyright holder. To view a copy of this licence, visit http://creativecommons.org/licenses/by/4.0/. 
ecoregions: the Paranaense Forest, the Chaco (Wet and Dry), and the subtropical jungles of the Yungas [2].

Propolis has relevant therapeutic properties that have been used since ancient times. Its antiseptic, antibacterial, antifungal, astringent, spasmolytic, anti-inflammatory, anesthetic, antioxidant, anti-ulcer, anticancer, and immunomodulatory effects have been demonstrated [3-5]. It is currently used as a dietary supplement, in the pharmaceutical industry and in clinical applications in veterinary medicine [5]. Honey bees' propolis is a resinous and balsamic material collected from vegetable sources and processed with the addition of some enzymes [6], while meliponines propolis also has wax and earth, a fact that accounts for the denomination of geopropolis [7].

S. jujuyensis Schrottky, known as "llana," "peluquerita," or "tapezuá," is one of the most notable stingless bees in the Chaco dry forest because it can supply large amounts of honey $[8,9]$. It has black hairs on its head, a bright face, light brown wings, and a metasoma with black setae on its apex.

T. fiebrigi Schwarz, also known as "rubito" or "gold pin" in Argentina and "jate'i" in Paraguay [7] is distributed in Argentina (Misiones, Tucumán), Bolivia (Santa Cruz), Brazil (Mato Grosso, Mato Grosso do Sul, Paraná, Rio Grande do Sul, São Paulo), and Paraguay (Cordillera, Misiones) [10, 11].

Among the antimicrobial activities of propolis, alcoholic extract of T. fiebrigi showed fungicidal properties against Candida glabrata and C. albicans [12]. The antiinflammatory activity of the alcoholic extract of T. fiebrigi propolis was evaluated by determination of the hyaluronidase enzyme, an indirect way of assessing antiinflammatory activity. Hyaluronic acid is an important component of the articular cartilage and plays an important role in the renewal of tissues [13]. Its cytotoxic action against leukemia cell lines, human cervical adenocarcinoma, and human prostate cancer was evaluated $[14,15]$.

Ferreira Campos et al. 2015 reported phenolic compounds, aromatic acids, alcohols, terpenes, and sugars in ethanol extracts of T. fiebrigi propolis. These compounds have been identified in other propolis studies of stingless bees found in Brazil [12-17]. In previous works, we revealed the presence of sterols, triterpenes, catechins, coumarins, flavonoids, phenols, tannins, and anthocyanidins in ethanol extracts of T. fiebrigi and S. jujuyensis propolis [18]. Furthermore, our group also reported on the antinociceptive, antioxidant and antibiofilm activities of ethanol extracts from stingless bee propolis to validate their traditional use [18]. The Wistar rat is a mammal that is an ideal model, because its genome is known, its size is easily manageable, it is easy to maintain, relatively economical, and it also has a short gestational period, large litters, and reaches sexual maturity very soon, by what have several generations in a short time. In this work, induced disease models are used, and induced models are healthy models in which the condition to be investigated is induced experimentally.

This study was undertaken to investigate propolis medicinal properties as an anti-inflammatory, antitussive, and expectorant in vivo. In addition, an evaluation of acute toxicity in vivo of the ethanol extracts of $S$. jujuyensis and $T$. fiebrigi propolis was conducted to propose this product as a potential phytopharmaceutical for the treatment of respiratory tract diseases that occur with inflammation, pain and dry unproductive cough.

\section{Methods}

\subsection{Chemicals}

The chemicals used in the study were of analytical grade and in good quality. Carrageenan, $\mathrm{NaCl}, \mathrm{NH} 4 \mathrm{OH}$, and phenol red were procured from Sigma-Aldrich Chemical Co. (St. Louis, MO, USA). Ibuprofene syrup (Laboratory Roemmers S.A.I.C.F, Argentina), codeine syrup (Laboratory Andromaco, Argentina), meprednisone oral solution (Laboratory Biotenk S.A., Argentina), and bromhexine hydrochloride syrup (Laboratory Boehringer Ingelheim, Germany) were obtained from the local pharmacy.

\subsection{Geopropolis sample}

In this work, we used propolis of S. jujuyensis and $T$. fiebrigi. The hives are located in the Famailla Agricultural Experiment Station of INTA, in the province of Tucumán, Argentina. Both species of bees were identified and deposited in the Museo de La Plata, La Plata, Argentina (MLP; Lanteri,A.). Codes of material studied: S. jujuyensis (Schrottky) 30-III-2012, Alvarez-LuciaGennari (MLP) and T. fiebrigi (Schwarz), 26III-2012, Alvarez-Lucia (MLP).

\subsection{Preparation of extracts}

The extraction of the propolis of both species was performed by maceration, using ethanol as the extraction solvent, for 5 days in the dark. The extracts were filtered through Whatman paper $\mathrm{N}^{\circ} 1$, and the supernatant was evaporated to dryness. The dry extract was stored in sterile Eppendorf at $4{ }^{\circ} \mathrm{C}$ until used. In this way, the ethanol extracts of $S$. jujuyensis (EPS) and $T$. fiebrigi (EPT) propolis were obtained.

\subsection{Animals}

Wistar male rats (weighing 190-240 g) were used for this study and were obtained from the Bioterio de la Facultad de Bioquímica, Química y Farmacia, Instituto de Biología (INSIBIO), Universidad Nacional de Tucumán. The rats were first left for 7 days to acclimatize to laboratory conditions. All animals were kept under normal laboratory conditions of humidity, temperature (25 
$\pm 1{ }^{\circ} \mathrm{C}$ ), and light (12hs dark/light cycle) and allowed free access to food and water ad libitum. The studies were conducted in accordance with the internationally accepted principles for laboratory animal use and care (EEC Directive of 1986; 86/609/EEC). The study protocol for antitussive, expectorant, anti-inflammatory, and acute toxicity evaluation of test propolis was approved by the Institutional Committee for the Care and Use of Laboratory Animals CICUAL), approval number: No. CICUAL 012/2018, dated July 14, 2019.

\subsection{Carrageenan-induced hind paw edema in rats}

Paw edema was induced in rats by carrageenan injection $0.1 \mathrm{~mL}$ of $1.5 \%(\mathrm{w} / \mathrm{v})$ into the sub plantar region of the right hind paw of the rats according to the method described by Winter et al. [19]. All rats (six per group) were given free access to food and water after the sub plantar injections. Control group rats received saline solution $[0.9 \%(\mathrm{w} / \mathrm{v}) \mathrm{NaCl}](2 \mathrm{~mL} / \mathrm{kg})$, and the reference group received $100 \mathrm{mg} / \mathrm{kg}$ ibuprofen, orally. The test groups of rats were treated orally with 250, 500, and $1000 \mathrm{mg} / \mathrm{kg}$ b.w. of the ethanol extracts of S. jujuyensis and T. fiebrigi propolis $30 \mathrm{~min}$ before the carrageenan injection. The paw volume was measured before administering carrageenan (Vo) and 1, 2, 3, 4, and $6 \mathrm{~h}$ after (Vt) with the help of digital vernier caliper (Wembley 5940). Inflammation was calculated as the increase in volume $(\mathrm{mL})$ of the paw after treatment subtracted of the basal volume. Results were expressed as percentage of inhibition of edema, calculated according to the following formula $\left[(V \mathrm{t}-V \mathrm{o}) / V_{\mathrm{o}}\right] \times 100[20]$.

\subsection{Cotton pellet-induced granuloma formation}

Male rats weighing $180-200 \mathrm{~g}$ were randomly divided into seven groups of six rats each. Two sterilized cotton pellets $(20 \pm 1 \mathrm{mg})$ were implanted subcutaneously, one on each side of the abdomen in all groups, under light ether anesthesia. Rats in group I (control group) received saline solution $[0.9 \%(\mathrm{w} / \mathrm{v}) \mathrm{NaCl}](2$ $\mathrm{mL} / \mathrm{kg}$ ), orally. Rats in groups II and III received ibuprofen and meprednisone, at the dose of 100 and 5 $\mathrm{mg} / \mathrm{kg}$ b.w./day, respectively. Rats in groups IV to VII received ethanol extracts of S. jujuyensis and T. fiebrigi propolis at the dose of 500 and $1000 \mathrm{mg} / \mathrm{kg}$ b.w./ day, respectively. Each test substance was administered for 7 days. On the eighth day, each rat was anesthetized. The rat was then sacrificed, and the implanted pellets as well as the thymus were dissected out and determined for their wet and dry weights (dried at $60 \pm 1{ }^{\circ} \mathrm{C}$ for $18 \mathrm{~h}$ ). The granuloma and transudative weights and the percent inhibition of granuloma formulation of the test compounds were calculated [21].

\subsection{Antitussive effects}

Male rats weighing 210-240 g were divided randomly, 6 rats per group. The negative control of animals was treated with saline solution $[0.9 \%(\mathrm{w} / \mathrm{v}) \mathrm{NaCl}](2 \mathrm{~mL} / \mathrm{kg})$ orally, and other groups received single daily dose of extracts $(125,250,500$, and $1000 \mathrm{mg} / \mathrm{kg}$ b.w.) and codeine phosphate syrup $(3 \mathrm{mg} / \mathrm{kg}$ b.w.) orally for 3 days, respectively. Antitussive activity was investigated on a classical cough model induced by ammonia liquor [22, 23], $30 \mathrm{~min}$ after oral administration of the test compounds, and each rat was placed in a $1000-\mathrm{mL}$ special glass chamber and exposed to $0.3 \mathrm{~mL} 25 \% \mathrm{NH}_{4} \mathrm{OH}$ produced by a nebulizer for $45 \mathrm{~s}$. During ammonia exposure, the animal was continuously monitored by a trained observer. The cough frequency and latent period of cough were recorded for $6 \mathrm{~min}$. The antitussive activity was assessed as the percentage of inhibition of the number of coughs in terms of that in control groups by using the following equation:

$\%$ inhibition $=[(\mathrm{CO}-\mathrm{Ct}) / \mathrm{C} 0 \times 100 \%], \mathrm{C} 0$ : the number of coughs of control, $\mathrm{Ct}$ : the number of coughs of the treatment groups.

\subsection{Expectorant activity of extracts}

Rats $(210-240 \mathrm{~g})$ were divided into 6 groups $(n=6)$. The control group received saline solution $[0.9 \%(\mathrm{w} / \mathrm{v}) \mathrm{NaCl}]$ $(2 \mathrm{~mL} / \mathrm{kg})$, and other groups received single daily dose of extracts $(125,250,500$, and $1000 \mathrm{mg} / \mathrm{kg}$ b.w.) and bromhexine syrup (12 mg/kg b.w.) oral for 3 days, respectively. One hour after the last drug administration, $5 \%$ of phenol red in saline solution $(500 \mathrm{mg} / \mathrm{kg}$ b.w.) is injected via intraperitoneal. After $30 \mathrm{~min}$, the rats were killed. The trachea was dissected free from adjacent organs and removed from the thyroid cartilage to the main stem bronchi and then put into $4.0 \mathrm{~mL}$ of saline solution, and $1 \mathrm{~mL}$ of this wash solution was measured and mixed with $0.5 \mathrm{~mL} \mathrm{NaOH}(1 \mathrm{~mol} / \mathrm{L})$. The optical density (OD) values were measured on a spectrophotometer with the wavelength of $546 \mathrm{~nm}$. The excretion of phenol red was determined according to the standard curve [23].

\subsection{Acute toxicity study in rats}

The animals were divided into three groups, with six animals each. They were treated orally with a single dose of the ESP and ETP dissolved in distilled water and at supra-therapeutic doses of 2000 and $5000 \mathrm{mg} / \mathrm{kg}$ in 10 $\mathrm{mL} / \mathrm{kg}$ volume. The control group received distilled water as a single dose, orally, in $10 \mathrm{~mL} / \mathrm{kg}$ volume. All animals were observed after treatment. The parameters evaluated were death, alertness, sedation, ptosis, dyspnea, urination, diarrhea, seizures, spontaneous motor activity, postural reflex, piloerection, and response to touch. Body weight, food, and water consumption were also monitored for 2 weeks. At the end of the 
experimental period, all animals were weighed and sacrificed, and organs were removed for necropsy [24, 25].

\subsection{Euthanasia and Anesthesia}

At the end of the evaluations, the death of the animals is induced humanely. Euthanasia is performed using (a) injection of chemical anesthetics (e.g., pentobarbital 120$210 \mathrm{mg} / \mathrm{kg}$ ) or (b) inhalant anesthetics, e.g., $\mathrm{CO} 2$ or isoflurane from a vaporizer.

\subsection{Statistical analysis}

Data obtained from animal experiments were expressed as the mean and standard error of the mean (mean \pm S.E.M.). Statistical differences between the treated and the control groups were evaluated by ANOVA and Dunnett's tests. The criterion for statistical significance was $p<0.05$.

\section{Results}

\subsection{Carrageenan-induced rat paw edema}

In the carrageenan test, the average right back paw edema volumes of the control and extract of treated groups are shown in Table 1. The injection of the phlogistic agent caused localized edema in the control group starting at $1.0 \mathrm{~h}$ after injection. The swelling increased progressively to a maximum volume of $2.42 \pm 0.36 \mathrm{~mL}$ at $4.0 \mathrm{~h}$ after the carrageenan injection. Rats previously treated with both geopropolis extracts suppressed the inflammatory response $1 \mathrm{~h}$ after injection with carrageenan. The highest anti-inflammatory action is still given by the lowest concentration tested $(250 \mathrm{mg} / \mathrm{kg}$ b.w.). This suppressive effect of the inflammation continued throughout the trial $(5 \mathrm{~h})$ for the ESP at all the doses tested and with values similar to the standard, ibuprofen $(100 \mathrm{mg} / \mathrm{kg}, \mathrm{po})$.

\subsection{Cotton pellet-induced granuloma formation}

Ibuprofen and meprednisone in a dose of 100 and $5 \mathrm{mg} /$ $\mathrm{kg} /$ day and ETP and ESP even at the lowest dose of 500 $\mathrm{mg} / \mathrm{kg}$ b.w. significantly reduced the transudative and granuloma weights, as shown by their granuloma inhibition of $45.56 \%, 57.10 \%, 45.12 \%$, and $36.43 \%$, respectively (Table 2). It was also found that dry thymus weights were not significantly different between the groups (control, ibuprofen, ETP, and ESP), except in the meprednisone group that revealed a significant decrease compared to the control group.

\subsection{Antitussive effects}

To evaluate the antitussive effects, the ammonia-induced cough model was adopted in rats; the results are presented in Table 3. Both ETP and ESP extracts $(125,250$, 500 , and $1000 \mathrm{mg} / \mathrm{kg}$ b.w.) significantly improved the latency period and they inhibited cough frequency compared to that of the negative control $p<0.05$. The highest percentages of inhibition of cough frequency correspond to ETP and ESP (1000 mg/kg b.w.) $78.46 \%$ and $78.46 \%$, respectively (Fig. 1), being similar to codeine ( $3 \mathrm{mg} / \mathrm{kg}$ b.w.) $75.00 \%$ used as positive control.

\subsection{Expectorant activity of extracts}

An experiment to compare ETP and ESP expectorant activities was performed, and the results are shown in Table 4. Compared with the negative control, bromhexine $(12 \mathrm{mg} / \mathrm{kg}$ b.w.) significantly increased the secretion of phenol red, by $89.17 \%(p<0.05)$. The ethanol extracts of both propolis analyzed did not present a significant expectorant activity in this experimental model.

\subsection{Acute toxicity}

Oral administration of the different doses of ESP and ETP at a doses of 2000 and $5000 \mathrm{mg} / \mathrm{kg}$ resulted in no mortality or clinical signs of acute toxicity in rats as

Table 1 Effect of ethanol extracts of propolis of T. fiebrigi (ETP) and S. jujuyensis (ESP) on edema carrageenan-induced rat paw edema

\begin{tabular}{|c|c|c|c|c|c|c|c|c|}
\hline \multirow{2}{*}{$\begin{array}{l}\text { Group } \\
(\boldsymbol{n}=6)\end{array}$} & \multirow{2}{*}{$\begin{array}{l}\text { Dose } \\
\text { (mg/ } \\
\mathrm{kg})\end{array}$} & \multicolumn{6}{|c|}{ Paw edema vol in $\mathrm{ml}$ (Mean \pm S.E.) } & \multirow[b]{2}{*}{$6 h^{a}$} \\
\hline & & $\mathrm{Oh}$ & $1 h^{a}$ & $2 h^{a}$ & $3 h^{a}$ & $4 h^{a}$ & $5 h^{a}$ & \\
\hline Control & S.S. & $1.42 \pm 0.16$ & $1.73 \pm 0.15$ & $2.00 \pm 0.20$ & $2.32 \pm 0.10$ & $2.42 \pm 0.36$ & $2.37 \pm 0.32$ & $2.13 \pm 0.31$ \\
\hline Ibuprofen & 100 & $1.40 \pm 0.15$ & $1.45 \pm 0.15^{*}$ & $1.40 \pm 0.10^{*}$ & $1.40 \pm 0.10^{*}$ & $1.45 \pm 0.15^{*}$ & $1.45 \pm 0.05^{*}$ & $1.55 \pm 0.15^{*}$ \\
\hline \multirow[t]{3}{*}{ ETP } & 250 & $1.40 \pm 0.13$ & $1.60 \pm 0.02$ & $1.80 \pm 0.02^{*}$ & $2.28 \pm 0.08$ & $2.37 \pm 0.32$ & $2.33 \pm 0.29$ & $2.07 \pm 0.42$ \\
\hline & 500 & $1.40 \pm 0.12$ & $1.57 \pm 0.06^{*}$ & $1.62 \pm 0.03^{*}$ & $1.90 \pm 0.10^{*}$ & $2.07 \pm 0.23$ & $1.93 \pm 0.25^{*}$ & $1.95 \pm 0.13^{*}$ \\
\hline & 1000 & $1.42 \pm 0.10$ & $1.50 \pm 0.02^{*}$ & $1.53 \pm 0.06^{*}$ & $1.55 \pm 0.05^{*}$ & $1.60 \pm 0.10^{*}$ & $1.67 \pm 0.12^{*}$ & $1.57 \pm 0.06^{*}$ \\
\hline \multirow[t]{3}{*}{ ESP } & 250 & $1.43 \pm 0.10$ & $1.45 \pm 0.05^{*}$ & $1.48 \pm 0.03^{*}$ & $1.73 \pm 0.12^{*}$ & $1.80 \pm 0.20^{*}$ & $1.80 \pm 0.10^{*}$ & $1.63 \pm 0.06^{*}$ \\
\hline & 500 & $1.43 \pm 0.15$ & $1.55 \pm 0.09^{*}$ & $1.65 \pm 0.13^{*}$ & $1.68 \pm 0.03^{*}$ & $1.73 \pm 0.06^{*}$ & $1.78 \pm 0.03^{*}$ & $1.68 \pm 0.03^{*}$ \\
\hline & 1000 & $1.42 \pm 0.13$ & $1.50 \pm 0.09^{*}$ & $1.53 \pm 0.08^{*}$ & $1.58 \pm 0.08^{*}$ & $1.62 \pm 0.03^{*}$ & $1.72 \pm 0.08^{*}$ & $1.55 \pm 0.05^{*}$ \\
\hline
\end{tabular}

Values are expressed in mean \pm S.E.M. $(n=6)$

s.s. saline solution

* Statistically different from control group: $p<0.05$

${ }^{\mathrm{a}}$ Time after carrageenan injection (h) 
Table 2 Effects of ethanol extracts of propolis of T. fiebrigi (ETP) and S. jujuyensis (ESP) on cotton pellet-induced granuloma formation in rats

\begin{tabular}{|c|c|c|c|c|c|}
\hline \multicolumn{6}{|c|}{ Cotton pellet-induced granuloma formation } \\
\hline & Dose & Transudative & Granuloma & Granuloma & Dry thymus \\
\hline Groups $(\boldsymbol{n}=6)$ & $(\mathrm{mg} / \mathrm{kg} / \mathrm{d})$ & weight (mg) & weight (mg) & inhibition (\%) & weight (mg/100 g BW) \\
\hline Control & SS & $594.35 \pm 25.60$ & $156.70 \pm 3.30$ & - & $30.49 \pm 2.06$ \\
\hline Ibuprofen & 100 & $178.90 \pm 15.50^{*}$ & $76.20 \pm 2.80^{*}$ & 45.56 & 33. $24 \pm 5.40$ \\
\hline Meprednisone & 5 & $165.10 \pm 14.85^{*}$ & $55.80 \pm 9.00^{*}$ & 57.10 & $22.61 \pm 3.95^{*}$ \\
\hline \multirow[t]{2}{*}{ ETP } & 500 & $357.40 \pm 86.60^{*}$ & $86.00 \pm 4.90^{*}$ & 45.12 & $32.50 \pm 6.50$ \\
\hline & 1000 & $368.50 \pm 34.10^{*}$ & $76.75 \pm 8.05^{*}$ & 51.02 & $33.43 \pm 4.30$ \\
\hline \multirow[t]{2}{*}{ ESP } & 500 & $427.00 \pm 42.00^{*}$ & $99.60 \pm 5.30^{*}$ & 36.43 & $34.15 \pm 3.50$ \\
\hline & 1000 & $384.50 \pm 52.60^{*}$ & $84.90 \pm 18.90^{*}$ & 45.80 & $33.81 \pm 3.80$ \\
\hline
\end{tabular}

Values are expressed as mean \pm S.E.M. $(n=6)$.

TrW transudative weight, GrW granuloma weight, Gl granuloma inhibition, BW body weight, $T W$ thymus weight, ss saline solution

*Significantly different from the control group, $p<0.05$

observed for a short period of $48 \mathrm{~h}$ and a prolonged period of 14 days. The 6 rats (both treated groups) survived until the end of the observation period. No abnormalities were found in the organs at autopsy. Additionally, no significant difference was observed in the body weights of the ETP and ESP-treated and control groups (Table 5). These results suggest that single oral doses of 2000 and $5000 \mathrm{mg} / \mathrm{kg}$ b.w. are safe to use in rats.

\section{Discussion}

Propolis has been used historically in ethnomedicine, to treat respiratory diseases. Traditional knowledge and reports of its popular use to relieve cough and inflammatory diseases [6] led us to evaluate the anti-inflammatory, antitussive, and expectorant effects of extracts of S. jujuyensis and T. fiebrigi propolis and determine their safety in the present study.
The carrageenan test was selected due to its sensitivity in the detection of active anti-inflammatory agents orally, particularly in the acute phase of inflammation [26, 27]. Carrageenan-induced rat paw edema is associated with three distinct phases [28]. The first phase is mediated early by mast cell degranulation and the release of histamine and serotonin $(60 \mathrm{~min})$, and the second phase (60 to $180 \mathrm{~min}$ ) is characterized by the release of bradykinins rather than eicosanoids such as prostaglandins, which are synthesized in large quantity during the last phase (180-240 min). Oral administration of the ethanol extracts of ESP and ETP propolis (in all the doses analyzed) suppressed the edematous response after $1 \mathrm{~h}$, and this effect continued until $5 \mathrm{~h}$, except at $250 \mathrm{mg} / \mathrm{kg}$ body weight of ETP. The effect observed in the extracts was similar to that of ibuprofen. The cotton pellet granuloma on the other hand, is a model of chronic inflammation. The dry weight of the pellet correlated well with the amount granulomatous tissue [21]. This test method has

Table 3 Effects of ethanol extracts of propolis of T. fiebrigi (ETP) and S. jujuyensis (ESP) on the ammonia liquor-induced cough in rats

\begin{tabular}{|c|c|c|c|c|c|}
\hline \multirow[t]{2}{*}{ Group } & \multirow{2}{*}{$\begin{array}{l}\text { Dose } \\
(\mathrm{mg} / \mathrm{Kg})\end{array}$} & \multirow{2}{*}{$\begin{array}{l}\text { Treatment } \\
\text { (p.o.) }\end{array}$} & \multicolumn{3}{|l|}{ Cough } \\
\hline & & & Latent period (s) & Cough Frequency & Inhibition (\%) \\
\hline Control & SS & 3 days & $10.80 \pm 1.13$ & $16.25 \pm 1.77$ & - \\
\hline Codeine phosphate & 3 & 3 days & $78.50 \pm 8.49^{*}$ & $4.00 \pm 1.41^{*}$ & 75.38 \\
\hline \multirow[t]{4}{*}{ ETP } & 125 & 3 days & $12.38 \pm 0.14$ & $9.50 \pm 0.71^{*}$ & 41.54 \\
\hline & 250 & 3 days & $17.75 \pm 0.35^{*}$ & $8.00 \pm 1.41^{*}$ & 50.77 \\
\hline & 500 & 3 days & $19.88 \pm 2.23^{*}$ & $6.00 \pm 1.50^{*}$ & 63.07 \\
\hline & 1000 & 3 days & $30.56 \pm 4.84^{*}$ & $3.50 \pm 0.50^{*}$ & 78.46 \\
\hline \multirow[t]{4}{*}{ ESP } & 125 & 3 days & $20.56 \pm 2.04^{*}$ & $9.50 \pm 0.71^{*}$ & 41.52 \\
\hline & 250 & 3 days & $24.10 \pm 0.57^{*}$ & $7.59 \pm 0.45^{*}$ & 53.29 \\
\hline & 500 & 3 days & $35.92 \pm 6.30^{*}$ & $4.00 \pm 1.41^{*}$ & 75.38 \\
\hline & 1000 & 3 days & $46.82 \pm 11.89^{*}$ & $3.50 \pm 0.66^{*}$ & 78.46 \\
\hline
\end{tabular}

Values are expressed as mean \pm SE $(n=6)$.

$s$ seconds, ss saline solution

${ }^{*} p<0.05$ compared with the control group 


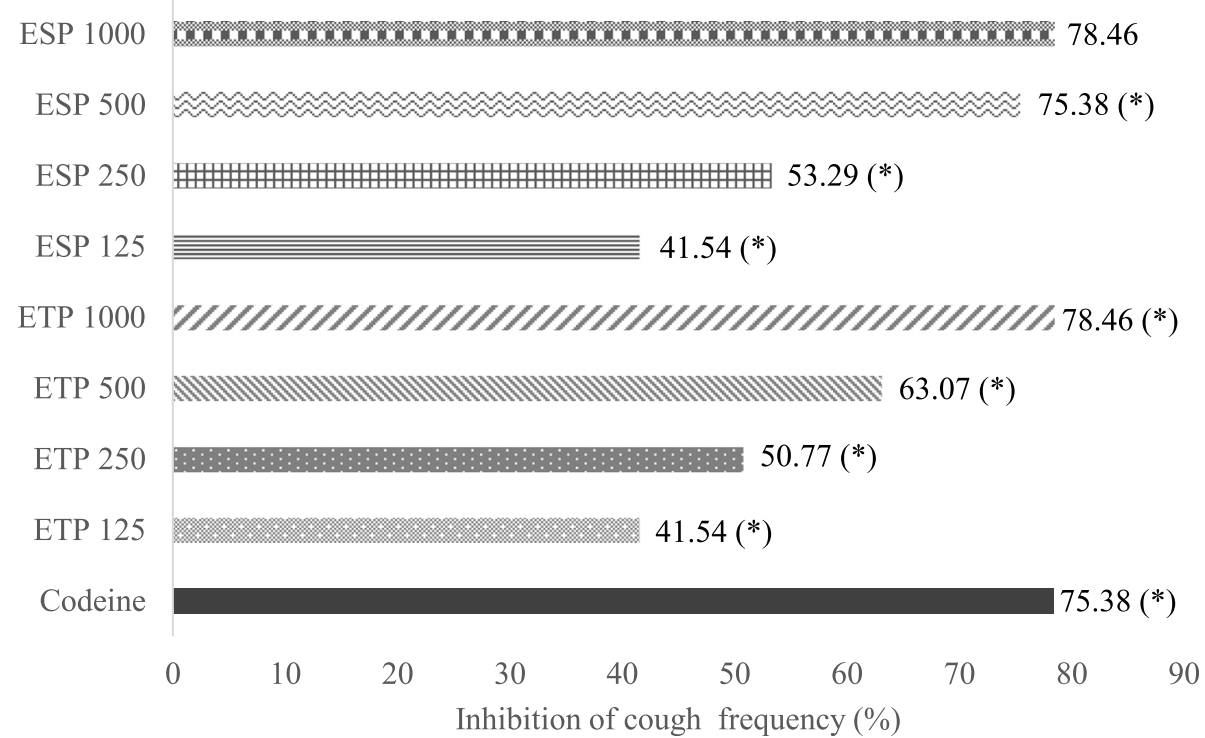

Fig. 1 Antitussive activity of ethanol extracts of S. jujuyensis and T. fiebrigi propolis. Values are expressed as mean $\pm \mathrm{SE}(n=6)$. ${ }^{*} p<0.05$ compared with the control group

been widely used to assess the transudative, exudative, and proliferative phases of chronic inflammation. ETP and ESP (500 and $1000 \mathrm{mg} / \mathrm{kg}$ b.w.) elicited significant inhibitory activity on the granuloma wet weight. This suggests an inhibitory effect of the extract on vascular permeability. When an assessment was made of the dry weight of the granuloma that showed the effect of the test substances on the proliferative phase of inflammation, the propolis ethanol extracts at the different doses

Table 4 Effects of ethanol extracts of propolis of T. fiebrigi (ETP) and S. jujuyensis (ESP) on the amount of phenol red secretion in rats

\begin{tabular}{lllll}
\hline Group & $\begin{array}{l}\text { Dose } \\
(\mathrm{mg} / \mathrm{kg})\end{array}$ & $\begin{array}{l}\text { Treatment } \\
(\text { p.o. })\end{array}$ & Absorbance & $\begin{array}{l}\text { Concentration } \\
\text { of phenol red } \\
(\mu \mathrm{g} / \mathrm{ml})\end{array}$ \\
\hline Control & Ss & 3 days & $0.1005 \pm 0.003$ & $0.8165 \pm 0.019$ \\
Bromhexine & 12 & 3 days & $0.2592 \pm 0.005$ & $2.1131 \pm 0.035^{*}$ \\
ETP & 125 & 3 days & $0.1002 \pm 0.005$ & $0.8102 \pm 0.016$ \\
& 250 & 3 days & $0.0995 \pm 0.005$ & $0.8115 \pm 0.035$ \\
& 500 & 3 days & $0.0935 \pm 0.005$ & $0.7592 \pm 0.035$ \\
& 1000 & 3 days & $0.0965 \pm 0.007$ & $0.7837 \pm 0.051$ \\
ESP & 125 & 3 days & $0.1004 \pm 0.007$ & $0.8164 \pm 0.051$ \\
& 250 & 3 days & $0.0988 \pm 0.005$ & $0.8128 \pm 0.035$ \\
& 500 & 3 days & $0.1015 \pm 0.007$ & $0.8247 \pm 0.051$ \\
& 1000 & 3 days & $0.0998 \pm 0.005$ & $0.8118 \pm 0.0351$ \\
\hline
\end{tabular}

Values are expressed as mean \pm SE $(n=6)$.

Ss saline solution

${ }^{*} p<0.05$ compared with the control group used were found to inhibit granuloma formation. Most non-steroidal anti-inflammatory drugs (NSAIDs) like ibuprofen only slightly inhibit granuloma formation. The steroidal drug, on the contrary, exhibits a marked reduction of the granuloma [29]. ETP and ESP reduced paw edema and inflammatory cell infiltration in a chronic inflammation. These results suggest that the antiinflammatory activity may be mediated by the inhibition of prostaglandin biosynthesis.

According to our knowledge, studies on the antiinflammatory activity of propolis obtained from stingless bees are scarcer. Our results constitute the first report of the anti-inflammatory activity of propolis from $T$. fiebrigi and S. jujuyensis. da Cunha et al. [30] evaluated the antiinflammatory activity of a benzophenone isolated from geopropolis of Melipona scutellaris by neutrophil migration in vivo and the quantification of TNF- $\alpha$, as well as by the quantification of TNF in vitro, phosphorylation of ERK 1/2, NF-kB activation, and nucleation of p65

Table 5 Body weight changes of rats in acute toxicity studies

\begin{tabular}{llllll}
\hline Group & Doses & $\boldsymbol{N}$ & \multicolumn{3}{l}{ Body weight $(\mathrm{g})$} \\
\cline { 3 - 6 } & & & Before study & $\mathrm{d} 7$ & $\mathrm{~d} 14$ \\
\hline Control & & 6 & $183.8 \pm 10.7$ & $211.2 \pm 9.7$ & $240.2 \pm 10.4$ \\
ETP & $2000 \mathrm{mg} / \mathrm{kg}$ & 6 & $180.6 \pm 12.5$ & $215.2 \pm 10.8$ & $235.3 \pm 12.5$ \\
& $5000 \mathrm{mg} / \mathrm{kg}$ & 6 & $185.2 \pm 11.1$ & $210.9 \pm 12.1$ & $232.8 \pm 11.4$ \\
ESP & $2000 \mathrm{mg} / \mathrm{kg}$ & 6 & $180.8 \pm 9.9$ & $209.2 \pm 10.4$ & $237.2 \pm 10.1$ \\
& $5000 \mathrm{mg} / \mathrm{kg}$ & 6 & $183.2 \pm 10.1$ & $213.9 \pm 10.1$ & $242.1 \pm 11.2$ \\
\hline
\end{tabular}

Date presented as mean \pm SD for $N=6$ 
translocation in stimulated macrophages. Other authors published the anti-inflammatory activity of propolis of Trigone sp. from Indonesia by inhibiting the expression of IL 6 in the tissue of the dental pulp of rats [14, 31].

Further, the present studies demonstrate a potent antitussive effect for both ETP and ESP propolis, even at the lowest dose tested $(125 \mathrm{mg} / \mathrm{kg}$ b.w.). They inhibited cough frequency, and they prolonged latent cough period, similar to that of known antitussive codeine. To the best of the authors' knowledge, this is the first study reporting the antitussive properties of stingless bee propolis. Previously, our group informed the antinociceptive, antioxidant, and antibiofilm activities of ethanolic extracts of T. fiebrigi and S. jujuyensis propolis to validate the traditional usage of this stingless bee's propolis [18].

Propolis is a heterogeneous product constituted by several groups of compounds. Moreover, the chemical composition depends strongly on the phytogeographic characteristics of the collection site. The distinct chemistry of propolis from diverse origins sometimes does not mean dissimilar properties [32, 33]. Propolis of Europe and Brazil with diverse chemical compositions possessed anti-inflammatory activities. In both cases, the mechanism was due to the inhibition of NO production [6]. Brodkiewicz et al. [18] reported that ethanol extracts of $T$ fiebrigi and S. jujuyensis propolis had a low content of phenolic compounds, flavonoids, and resins and a high content of waxes. Similar results were obtained by Franchin et al. [34] and Bankova [35]. Although meliponid hive products have many advantages, and meliponiculture has not become popular in Argentina yet, as it has in Mexico and Brazil. The studies published on these species are very scarce and have not been carried out at the same chemical and pharmacological level.

Our results signify that these geopropolis alcoholic extracts are an important source of natural analgesics, antioxidants, and antipathogenics which might play a vital role as novel potential therapeutic agents for the alleviation of infection and inflammatory pain. Chemical compounds of a non-phenolic nature would be responsible for the observed activity. Additionally, more investigations are in progress to explain the anti-inflammatory and antitussive mechanism(s) of geopropolis, chemical composition standardizing and chronic toxicity study could be clarified in further studies.

\section{Conclusions}

This study demonstrated significant antitussive and antiinflammatory effects of ethanol extracts of S. jujuyensis and T. fiebrigi propolis in animal models. These results are an important evidence for the validation of traditional use of propolis in the treatment of respiratory diseases which present as symptoms cough and inflammation.
However, further studies on isolation of bioactive compounds, establishment of structure activity relationship, and analysis of the molecular mechanisms responsible for its antitussive and anti-inflammatory potential will help in considering these natural resources in the treatment of upper respiratory tract diseases that occur with dry cough, pain, and inflammation.

\section{Abbreviations \\ ESP: Ethanol extracts of Scaptotrigona jujuyensis; ETP: Ethanol extracts of Tetragonisca fiebrigi; p.o: Per oral; NaCl: Sodium chloride; w: Weight; v: Volume; bw: Body weight; Vt: Paw volume after treatment subtracted of the basal volume; Vo: Paw volume before administering carrageenan; d: Days; g: Gram; m: Milligram; kg: Kilogram; mL: Milliliter; $\mathrm{NH}_{4} \mathrm{OH}$ : Ammonium hydroxide; s: Seconds; $\mathrm{CO}$ : The number of coughs of control; Ct: The number of coughs of the treatment groups; OD: Optical density; $\mathrm{NaOH}$ : Sodium hydroxide; L: Liter; nm: Nanometer; h: Hours; NSAIDs: Non-steroidal anti-inflammatory drugs; TNF-a: Tumor necrosis factor- a; ERK1/2: Extracellular signal-regulated kinases; NF-kB: Kappa nuclear transcription factor; sp: Species; IL 6: Interleukin 6; NO: Nitric oxide; MLP: Museo de La Plata}

\section{Acknowledgements}

The authors would like to thank Luis Maldonado and Gerardo Gennari for the propolis samples (INTA).

\section{Authors' contributions}

IB performed the experiments with stingless bee and analyzed the results. MR analyzed the results, reading, editing, and revision the manuscript. NR conceived the study idea, analyzed the results, reading, editing, and wrote the manuscript. All authors read and approved the final manuscript.

\section{Funding}

This research was supported by the Secretaria de Ciencia, Arte e Innovación Tecnológica de la Universidad Nacional de Tucumán.

\section{Availability of data and materials}

The datasets used and/or analyzed during the current study are available from the corresponding author on reasonable request.

\section{Ethics approval and consent to participate}

The studies were conducted in accordance with the internationally accepted principles for laboratory animal use and care (EEC Directive of 1986; 86/609/ $\mathrm{EEC})$. All the experimental protocols were approved by the institutional committee for the care of laboratory animals of the National University of Tucumán (CICUAL).

\section{Consent for publication}

Not applicable.

\section{Competing interests}

The authors declare that they have no competing interests.

\section{Author details \\ ${ }^{1}$ Facultad de Bioquímica, Química y Farmacia, Cátedra de Farmacoquímica, Inst. de Estudios Farmacológicos, Universidad Nacional de Tucumán, Ayacucho 471, 4000 Tucumán, Argentina. ${ }^{2}$ CONICET Consejo Nacional de Investigaciones Científicas y Técnicas, Universidad Nacional de Tucumán, Ayacucho 471, 4000 Tucumán, Argentina.}

Received: 9 January 2020 Accepted: 26 May 2020

Published online: 10 August 2020

\section{References}

1. O'Toole C (1993) Diversity of native bees and agroecosystems. In: LaSalle J, Gauld ID (eds) Hymenoptera and Biodiversity. Cab International, Wallingtord 2. Baquero L, Stamatti G, (2007) Cría y manejo de abejas sin agujón. Ediciones del Sub-trópico. ISBN: 978 987-23533-2-2. Salta, Argentina. 
3. Wagh V (2013) Propolis: a wonder bees product and its pharmacological potencials. Adv Pharmacol Sci.:1-11

4. Sawicka D, Car H, Borawska MH, Niklinski J (2012) The anticancer activity of propolis. Folia Histochem Cytobiol. 50(1):25-37

5. Banskota AH, Tezuka Y, Kadota S (2001) Recent progress in pharmacological research of propolis. Phytother Res. 15(7):561-571

6. Miguel M, Antunes M (2011) Antunes M. Is propolis safe as an alternative medicine? J Pharm Bioallied Sci. 3(4):479-495

7. Bankova V (2005) Chemical diversity of propolis and the problem of standardization. J Ethnopharmacol. 100:114-117

8. Nogueira-Neto P (1997) Vida e Criação de Abelhas Indígenas sem Ferrão. Nogueirapis (Ed), São Paulo, Brasil

9. Arenas P (2005) Etnografía y alimentación entre los toba-ñachilamoleek y wichí-lhuku'tas del Chaco Central (Argentina). Journal de la société des américanistes 91(1):236-239

10. APCD, (2005) Enseñanzas y cuentos de los Wichi sobre las mieles de monte Abejas indígenas sin aguijón: (Edición del autor Bilingüe Español-Wichi). Asociación Para la promoción de la Cultura y el Desarrollo. Las Lomitas, Formosa, Argentina, P: 88.

11. Camargo J, Pedro S (2007) Catalogue of bees (Hymenoptera, Apoidea) in the Neotropical Region. Sociedad e Brasilera de Entomologia:272-578

12. Ferreira Campos J, Pereira dos Santos U, Dos Santos da Rocha P, Damião M, Benedito Perrella Balestieri J, Lima Cardoso C, Paredes-Gamero E, Miranda Estevinho L, Souza K, dos Santos E, (2015) Antimicrobial, antioxidant, antiinflammatory, and cytotoxic activities of propolis from the stingless bee Tetragonisca fiebrigi (Jataí). Evid Based Complement Alternat Med. 1-11.

13. Kujumgiev A, Tsvetkova I, Serkedjieva Y, Bankova V, Christov R, Popov S (1999) Antibacterial, antifungal and antiviral activity of propolis of different geographic origin. J Ethnopharmacol. 64:235-240

14. Silva J, Rodrigues S, Feás X, Estevinho L (2012) Antimicrobial activity, phenolic profile and role in the inflammation of propolis. Food Chem Toxicol 50(5):1790-1795

15. Franchi Jr, G, Moraes C, Toreti V, Daugsch A, Nowill A, Park Y, (2012) Comparison of effects of the ethanolic extracts of Brazilian propolis on human leukemic cells as assessed with the MTT assay. Evid base Compl Alternative Med.1- 6 .

16. Szliszka E, Sokół-Łętowska A, Kucharska A, Jaworska D, Czuba Z, Król W, (2013) Ethanolic extract of polish propolis: chemical composition and TRAILR2 death receptor targeting apoptotic activity against prostate cancer cells. J Evid Based Complementary Altern Med. 1-12.

17. Miorin P, Levy N Jr, Custodio A, Bretz W, Marcucci M (2003) Antibacterial activity of honey and propolis from Apis mellifera and Tetragonisca angustula against Staphylococcus aureus. J Appl Microbiol. 95(5):913-920

18. Brodkiewicz Y, Marcinkevicius K, Reynoso M, Salomon V, Maldonado L, Vera N (2018) Biological and therapeutic effects of Argentine stingless bee propolis. J. Drug Deliv. Ther. 8(5):382-392

19. Winter C, Risley E, Nuss G (1962) Carrageenan-induced edemas in hind paw of the rats as an assay of anti-inflammatory drugs. P Soc Exp Biol Med. 3 544-547

20. García M, Fernández M, Sáenz M, Ahumada M (1996) Antiinflammatory effects of different extracts and harpagoside isolated from Scrophularia frutescens L. Farmaco 51:443-446

21. Pingsusaen P, Kunanusorn P, Khonsung P, Chiran T, Nattha K (2015) Investigation of anti-inflammatory, antinociceptiveand antipyretic activities of Stahlianthus involucratus rhizome ethanol extract. J Ethnopharmacol. 162: 199-206

22. Shang J, Cai X, Zhao Y, Feng T, Luo X (2010) Pharmacological evaluation of Alstonia scholaris: anti-tussive, anti-asthmatic and expectorant activities. $J$ Ethnopharmacol. 129:293-298

23. Liu L, Wang L, Liu X (2009) Comparison of antitussive, expectorant and antiasthmatic activities of different extracts from Ficus microcarpa. J Med Plants Re. 3(8):596-599

24. OECD, (2001). OECD Guidelines for testing of chemicals: acute oral toxicity acute toxic class method. Test No. 423, Adopted 22nd March 1996, and Revised Method Adopted 17th December 2001. OECD, Paris

25. Reynoso M, Daud A, Belizan M, Sánchez Riera A, Vera N (2016) Antinociceptive, Anti-inflammatory Effects and Safety of Ziziphus mistol Fruits. Int J Pharm Sci Drug Res. 8(2):103-110

26. Rosidah Yam M, Amirin S, Mariam A, Gabriel A, Zaini Mohd A (2009) Toxicology evaluation of standardized methanol extract of Gynura procumbens. J Ethnopharmacol. 123:244-249
27. Lin B, Li P, Wang Y, Wei P, Zhong W, Su W (2008) The expectorant activity of naringenin. Pulm Pharmacol Ther. 21:259-263

28. Rakesh K, Nirpesh S, Vishal P, Sandeep A (1972) Various animal models for preclinical testing of anti-inflammatory agents. Int J Pharm Sci Res. 8(4): 1550-1557

29. Reynoso M, Sánchez Riera A, Vera N (2016) Nutraceutical properties and safety evaluation of fruits and arrope of Geoffroea decorticans (Chañar). J Nutrit Health Food Sci. 6:1-8

30. da Cunha MG, Franchin M, de Paula-E LF, Freires IA, Beutler JA, de Alencar SM, Ikegaki M, Tabchoury C, Pereira Machado Cunha T, Mattar R, Pedro L (2016) Anti-inflammatory and anti-biofilm properties of ent-nemorosone from Brazilian geopropolis. J. Funct Foods. 26:27-35

31. Valenzuela-Barra G, Castro C, Figueroa C, Barriga A, Silva X, De las Heras B, Hortelano S, Delporte C, (2015) Anti-inflammatory activity and phenolic profile of propolis from two locations in Región Metropolitana de Santiago, Chile. J Ethnopharmacol. 168: 37-44.

32. Franchin M, Almeida Freires I, Goldoni Lazarini J, Dias Nani B, Guilhermeda Cunha M, Colon D (2017) The use of Brazilian propolis for discovery and development of novel anti-inflammatory drugs. Eur J Med Chem. 153:49-55

33. Sabir A, Sumidarti A (2017) Interleukin-6 expression on inflamed rat dental pulp tissue after capped with Trigona sp. propolis from south Sulawesi, Indonesia. Saudi j biol sci. 24:1034-1037

34. Franchin M, Cunha M, Denny C, Napimoga MH, Cunha TM, Bueno Silva B, Alencar SM, Ikegaki M, Rosalen PL (2013) Bioactive fraction of geopropolis from Melipona scutellaris decreases neutrophils migration in the inflammatory process: involvement of nitric oxide pathway. Evid base Compl Alternative Med. p. 1-9.

35. Bankova V (2005) Recent trends and important developments in propolis research. Evid Based Complement Alternat Med. 2(1):29-32

\section{Publisher's Note}

Springer Nature remains neutral with regard to jurisdictional claims in published maps and institutional affiliations.

\section{Submit your manuscript to a SpringerOpen ${ }^{\circ}$ journal and benefit from:}

- Convenient online submission

- Rigorous peer review

- Open access: articles freely available online

High visibility within the field

- Retaining the copyright to your article

Submit your next manuscript at $>$ springeropen.com 